\title{
Thermodynamic investigation and optimization Tri-generation system for the provision of power, heating, and cooling: A case study of Zahedan, Iran
}

\author{
Amir Ghasemkhani, Said Farahat*, Mohammad M. Naserian \\ Department of Mechanical Engineering, University of Sistan and Baluchestan, Zahedan, Iran
}

Corresponding Author Email: farahat@hamoon.usb.ac.ir

https://doi.org/10.18280/ijht.360317

Received: 5 December 2017

Accepted: 20 April 2018

\section{Keywords:}

exergy analysis, kalina cycle, trigeneration, solar energy, finite time thermodynamics

\begin{abstract}
The main purpose of this research is the thermodynamic analysis of the trigeneration system based on energy efficiency, exergy efficiency, and power. The trigeneration system under study consists of three subsystems that including the solar subsystem, Kalina subsystem, and lithium bromide-water absorption chiller subsystem. The proposed system generates power, cooling and hot water by using solar energy. The system studied is designed and analyzed based on the weather condition in Zahedan, Iran. According to the exergy analysis, the most exergy destruction rate takes place in the solar cycle. The results of the base-case analysis demonstrate that energy and exergy efficiencies and total cost rates are $17.37 \%$, $18.82 \%$ and 9.63 dollars per hour, respectively. Furthermore, comparison of optimization criteria such as energy efficiency, exergy efficiency, and power are discussed. The results show power is the best criteria for thermodynamic optimization. The results of trigeneration system optimization based on maximum power criterion show that produced power, energy efficiency, exergy efficiency and total cost rate increase $28 \%, 12.32 \%, 13.97 \%$ and $7.68 \%$, respectively in comparison with the base-case. As a result, this research is proved that thermodynamic investigation is closer to the ideal state in power criterion.
\end{abstract}

\section{INTRODUCTION}

Sustainable Development is defined as a human development mode that uses energy sources conditionally so as not to have an undesirable impact on the environment, and future generation needs. The relationship between energy, the environment, and sustainable development is similar to the three vertices of a triangle [1]. Therefore, the balance between energy, the environment, and sustainable development must be maintained. Presently, most production power of societies is supplied by fossil fuels such as coal and natural gas, while these fuels are polluting the environment. On the other hand, renewable energy such as solar energy, geothermal energy, biomass and wind energy are clean energies. The energy crisis and the pollution of fossil fuels show the growing importance of renewable energies. This pollution causes extreme weather, global warming, and ecosystem changes. The continuation of these conditions gradually causes the earth to be uninhabitable for humans. The prediction of carbon dioxide production in the world suggests that environmental pollution will increase in the future, which threatens the health of humans and other living organisms [2]. Among renewable energies, solar energy is even more important for researchers because the solar potential and exergy of the solar radiation are very high. However, using solar energy has also problems such as high cost, low received solar radiation efficiency, and high optical losses, and thermal losses. Also, climate change leads to discontinuities in solar radiation. There are many renewable energy projects in comprehensive plans such as the United States, China, and etc. [3].

The storage of thermal energy has been affected by modern technologies. The discontinuity of solar radiation has caused that solar systems have required saving energy, specifically, when the solar radiation is low, for example at night and on cloudy days. Usually, thermal energy storage (TES) is used to reduce initial costs and operational costs [4].

Recently, researchers have produced purposes such as hot water, hydrogen and fresh water from the primary source of energy. They have gone beyond single generation system, they have been able to produce more than one purposes using the waste energy. Ahmadi and Dincer [5] performed the exergoenvironmental analysis and optimization of cogeneration system that produced $50 \mathrm{MW}$ of electricity and $33.3 \mathrm{~kg} / \mathrm{s}$ of saturated vapor at a pressure of $1.3 \mathrm{bar}$. In their research, they presented a new objective function that included operational cost, fuel cost and environmental parameters such as the cost of pollutant. They calculated the minimum of the objective function by the genetic algorithm. They demonstrated the increase in fuel costs increased isentropic compressor efficiency, isentropic turbine efficiency, and turbine input temperature. Ahmadi et al. [6] modeled a trigeneration system that produced cooling, heating, and power. The trigeneration system consists of a gas turbine cycle, a Rankine cycle, a single effect absorption chiller, and a domestic water heater. Also, the parametric study results showed that compressor pressure ratio, inlet gas turbine 
temperature and isentropic gas turbine efficiency significantly affect exergy efficiency and environmental impacts of the system. Khaliq [7] investigated a multigeneration system with production cooling, heating, and power. They showed that exergy destruction in the combustion chamber and heat recovery steam generation (HRSG) are significantly affected by overall pressure ratio and inlet turbine temperature. Ahmadi et al. [8] studied a trigeneration system with thermodynamic purposes such as cooling, heating, and electricity. The trigeneration system consists of a gas turbine cycle, a steam turbine cycle and a single effect absorption chiller. Consequently, trigeneration and cogeneration systems are considered as a way to increase the system efficiency and reduce irreversibility.

Kalina cycle is a thermodynamic cycle that uses the ammonia-water mixture as the working fluid. A good feature of the ammonia-water mixture matches to thermal source compared to pure water [9]. Wall et al. [10] studied the Kalina cycle from the perspective of exergy. They proved that the efficiency of the Kalina cycle optimized by $10 \%$ more than the Rankine cycle. Wang et al. [11] examined the Kalina cycle that used solar energy. They proved that thermal storage system to ensure system stability. They have proven that thermal storage system provides thermal energy when solar radiation is not sufficient.

Absorption chiller produces Cooling from an independent heat source or the waste heat of other cycles like the solar cycle, Rankine cycle and Brayton cycle. Chua et al. [12] modeled an irreversible absorption chiller. Thermodynamics analysis and describing the absorption chiller process were studied base on Colburn-Drew Equations. Also, the assessment of the effect of different system irreversibility on absorption chiller performance was carried out by general macroscopic Equation. Farshi et al. [13] analyzed the exergyeconomics of three classes of double effect lithium-bromide and water based on refrigeration system, to evaluate overall systems and product cost flow rates. Their results are helpful in choosing, designing and improving lithium-bromide and water on based refrigeration systems in demonstrating the advantages and disadvantages of the two lithium-bromide absorber properties and water from the economic point of view.

The current study has the perspective of sustainable development by minimizing the cost and increasing the production power of renewable energy. This research has implemented the concepts of thermodynamics for the analysis of a trigeneration system with producing cooling, heating, and power. The novelty of this research is power analysis and it's compared with classical thermodynamic analysis such as energy and exergy efficiencies analysis. Another innovation in this study is the use of the Kalina cycle instead of the Rankine cycle.

\section{SYSTEM DESCRIPTION}

The schematic of the trigeneration system is presented in figure 3 . The system under study consists of three subsystems. The first subsystem is the solar cycle. Solar energy is received by parabolic trough collectors, Optical and thermal losses reduce the amount of heat transfer to the heat transfer fluid. The heat transfer fluid is the Therminol-66. In order to ensure the uniformity of the heat source thermal storage is used. When the amount of solar radiation is reduced, for example at night and cloudy days, thermal storage supplies the energy required to operate the system. The second subsystem is lithium bromide and water absorption chiller that provides heat from the solar cycle. The studied system is evaluated based on weather conditions in Zahedan. Figure 1. displays Global, beam and diffuse radiation in Zahedan. Hence, the average global solar radiation is $194 \mathrm{kWh} / \mathrm{m}^{2}$ in 10 years. As shown in figure. 2 , average ambient temperature and relative humidity are $20.2^{\circ} \mathrm{C}$ and 24 in Zahedan. Input data of the studied system is tabulated system in Table 1. Figure 1 reveals that global radiation peaked in June.

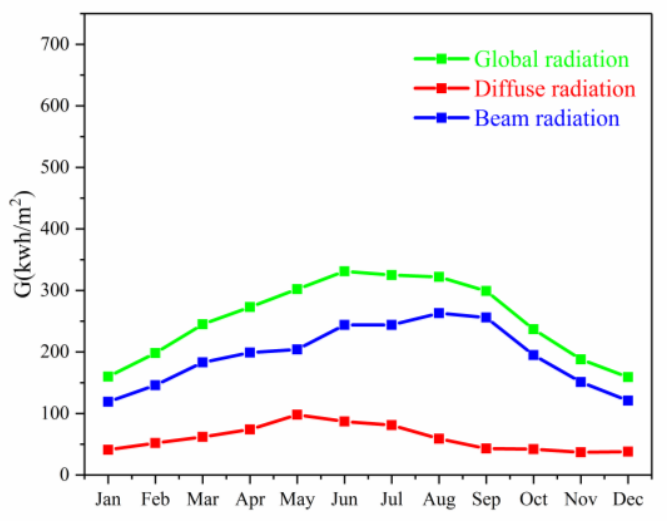

Figure 1. Global, beam and diffuse radiation in Zahedan

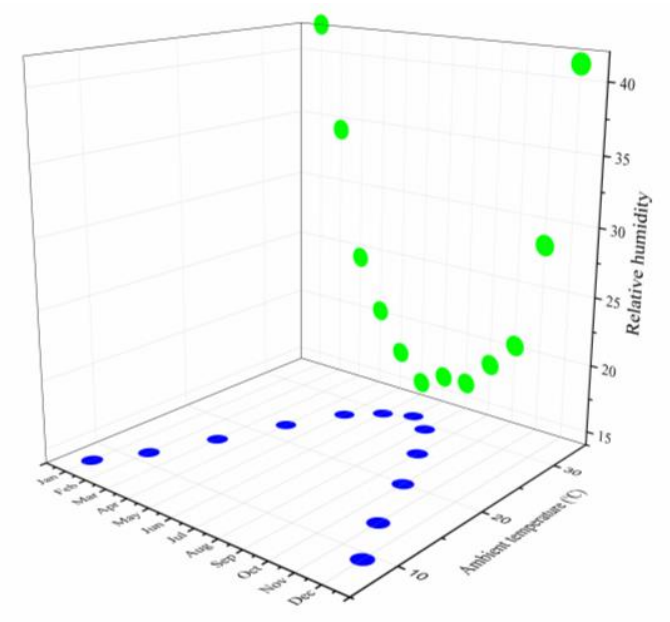

Figure 2. Ambient temperature and relative humidity in Zahedan

Table 1. Input date trigeneration system

\begin{tabular}{cc}
\hline \multicolumn{2}{c}{ Parabolic trough solar collectors } \\
\hline Collector type & LS-3 \\
\hline Heat transfer fluid & Therminol -66 \\
\hline Absorption chiller & 1.5 \\
\hline $\begin{array}{c}\text { Absorption Chiller Evaporator } \\
\text { Temperature }\left({ }^{\circ} \mathrm{C}\right)\end{array}$ & 89.4 \\
\hline $\begin{array}{c}\text { Absorption chiller generator } \\
\text { Temperature }\left({ }^{\circ} \mathrm{C}\right)\end{array}$ & 32.9 \\
\hline $\begin{array}{c}\text { Absorption chiller } \\
\text { absorption temperature }\left({ }^{\circ} \mathrm{C}\right)\end{array}$ & 39.9 \\
\hline $\begin{array}{c}\text { Absorption chiller } \\
\text { condenser temperature }\left({ }^{\circ} \mathrm{C}\right)\end{array}$ & Kalina cycle \\
\hline Working fluid & 20 \\
\hline Ammonia concentration $(\%)$ & Amonia-water \\
\hline
\end{tabular}




\section{ENERGY AND EXERGY ANALYSIS}

Energy consists of the sum of anergy and exergy. Anergy is defined as waste energy and exergy based on the maximum work; in other words, useful energy. Thermodynamic systems are evaluated based on energy conservation and also exergy balance according to the first and second law of thermodynamics, respectively [14]

\subsection{Parabolic trough solar collector}

Parabolic trough collectors are high-temperature and concentrating collectors. These collectors have a temperature range of $60-400^{\circ} \mathrm{C}$ and concentration ratio of $10-85$ and also a tube absorber. The useful collector heat is written as follows [15]:

$Q_{u}=F_{R} A_{a}\left[S-\frac{A_{r}}{A_{a}} U_{L}\left(T_{f}-T_{a}\right)\right]$

In equation (1), $T_{f}$ is the inlet collector temperature. The average solar radiation in Zahedan city, the Islamic Republic of Iran in 10 years (2006-2016) is $386 \mathrm{~W} / \mathrm{m}^{2}$. The absorbed solar radiation in the collector is obtained as follows:

$$
S=I_{a p} \tau \rho \alpha
$$

In equation (2), $I_{a p}$ is the received radiation measured on the plane of the aperture, $\tau$ is transmissivity of the concentrator, $\rho$ is the reflection coefficient of the concentrator, and $\alpha$ is the absorptivity of the concentrator. The absorber tube area is calculated as follows:

$A_{r}=\pi D_{o} \mathrm{~L}$

In equation (3), $\mathrm{D}_{\mathrm{o}}$ is the outer absorber diameter and $\mathrm{L}$ is length of the collector.

The collector aperture area is calculated as follows:

$A_{a}=(w-D) \mathrm{L}$

In equation (4), $\mathrm{w}$ is an aperture and $\mathrm{D}$ is the outer absorber cover diameter.

So, the heat removal factor is calculated as follows [16]:

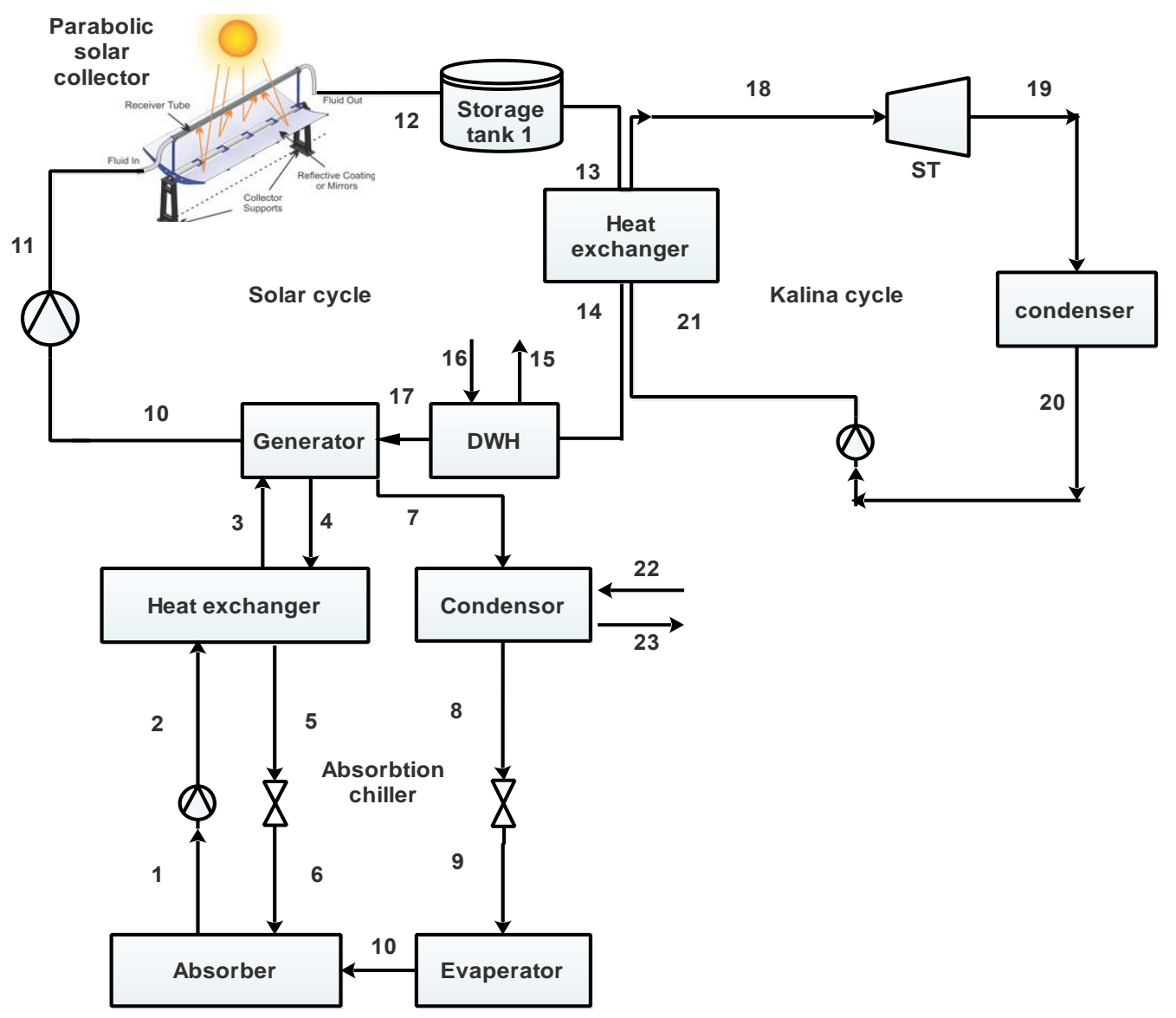

Figure 3. Schematic of trigeneration system for the provision of heating, cooling, and hot water

$F_{R}=\frac{\dot{m}_{s c} c_{p}}{A_{r} U_{L}}\left[1-\exp \left(\frac{A_{r} U_{L} F^{\prime}}{\dot{m} c_{p}}\right)\right]$

In equation (5), $c_{p}$ is the thermal capacity of the heat transfer fluid, $\dot{m}_{H T F}$ is the mass flow rate of the heat transfer fluid, $U_{L}$ is the total heat transfer coefficient, $A_{r}$ is the absorber area, and $\mathrm{F}^{\prime}$ is the thermal efficiency factor. The thermal efficiency factor is defined as:

$$
F^{\prime}=\frac{\frac{1}{U_{L}}}{\frac{1}{U_{L}}+\frac{D_{o}}{H_{t e} D_{i}}+\frac{D_{O}}{2 k} l n \frac{D_{0}}{D_{i}}}
$$

In equation (6), $H_{t e}$ is the coefficient of heat transfer on the inside surface of the tube, $D_{i}$ is the absorber inner diameter, and $\mathrm{k}$ is conductivity of absorber tube [16-19]. 


\subsection{Thermal storage}

Variable and unpredictable of solar radiation is an implementation problem of solar systems. Accordingly, the usage of thermal storage is essential in solar systems. The energy balance for the storage tank is written as follows:

$Q_{s}=Q_{s c}-Q_{\text {loading }}-Q_{l}$

In equation (7), $Q_{S}$ is the heat stored in the tank, $Q_{s c}$ and $Q_{\text {loading }}$ are the rates of addition or removal of energy from the collector, and $Q_{1}$ is tank heat losses. The energy stored in the tank is expressed as follows:

$\mathrm{Q}_{\mathrm{s}}=\mathrm{Mc}_{\mathrm{p}} \frac{\mathrm{dT}_{\mathrm{s}}}{\mathrm{dt}}$

where $T_{s}$ is thermal storage temperature. The heat transfer coefficient $U$ between the air and fluid is calculated as follows:

$\frac{1}{U A}=\frac{1}{h A}+\frac{\xi}{k A}$

where $\xi$ is the insulation thickness, and $\mathrm{k}$ is the thermal conductivity. $\dot{Q}_{1}$ can be found using the following equation (10).

$\dot{Q}_{t l}=\mathrm{UA}\left(T_{\mathrm{i}}-T_{0}\right)$

In the equation (10), $\mathrm{T}_{\mathrm{i}}$ is inlet HTF temperature in thermal storage and $\mathrm{T}_{0}$ is the ambient temperature [15, 20-22].

\subsection{Domestic water heater}

The heat transfer fluid passes through the boiler and enters the domestic water heater, and the water is heated to $60^{\circ} \mathrm{C}$. The energy balance of the domestic water heater is written as follows:

$\dot{Q}_{d w h}=\dot{m}_{s c}\left(h_{30}-h_{17}\right)=\dot{m}_{w}\left(h_{32}-h_{31}\right)$

where $\dot{\mathrm{m}}_{\mathrm{sc}}$ is mass flow rate of the solar cycle.

\subsection{Boiler}

The boiler is part of the system that transfers heat from the solar cycle to the Kalina cycle. In this paper, the boiler is a heat exchanger between the solar cycle and Kalina.

$\dot{Q}_{\text {boiler }}=\mathrm{UA}\left(T_{13}-T_{14}\right)$

$\mathrm{U}$ is the total heat transfer coefficient and $\mathrm{A}$ is the surface boiler.

\subsection{Absorption chiller generator}

The Absorption chiller generator is the required heat from the solar cycle. The heat transmitted to the generator is calculated using the following equation (13):

$\dot{Q}_{g e n}=\dot{m}_{s c}\left(h_{17}-h_{10}\right)$

Therefore, the energy balance for the generator can be written as follows: $\dot{m}_{3} h_{3}+\dot{Q}_{g e n}=\dot{m}_{4} h_{4}+\dot{m}_{7} h_{7}$

The destruction exergy for the generator is calculated as follows:

$\dot{E} x_{d, g e n}=\dot{E} x_{3}+\dot{E} x_{g e n}-\dot{E} x_{4}-\dot{E} x_{7}$

$\dot{E} x_{g e n}=\left(1-\frac{T_{0}}{T_{g e n}}\right) \dot{Q}_{g e n}$

$\dot{E x_{3}}=\dot{m}_{3}\left(h_{3}-h_{0}\right)-T_{0}\left(S_{3}-S_{0}\right)$

$\dot{E} \dot{x}_{4}=\dot{m}_{4}\left(h_{4}-h_{0}\right)-T_{0}\left(S_{4}-S_{0}\right)$

$\dot{E} \dot{x}_{7}=\dot{m}_{7}\left(h_{7}-h_{0}\right)-T_{0}\left(S_{7}-S_{0}\right)$

\subsection{Absorption chiller heat exchanger}

The mass balance for the absorption chiller heat exchanger is expressed as follows:

$\dot{m}_{2}=\dot{m}_{3}$

$\dot{m}_{4}=\dot{m}_{5}$

The energy and exergy balance for the heat exchanger of absorption chiller are calculated as follows:

$\dot{m}_{4}\left(h_{4}-h_{5}\right)=\dot{m}_{2}\left(h_{3}-h_{2}\right)$
$\dot{E} x_{d, h e x}=\dot{m}_{4}\left(\dot{E} x_{4}-\dot{E} x_{5}\right)-\dot{m}_{2}\left(\dot{E} x_{3}-\dot{E} x_{2}\right)$

\subsection{Absorption chiller condenser}

The mass balance equation for the adsorption chiller condenser is obtained as follows:

$\dot{m}_{7}=\dot{m}_{8}$

$\dot{m}_{8} h_{8}+\dot{Q}_{\text {con }}=\dot{m}_{7} h_{7}$

The exergy balance for the adsorption chiller condenser is calculated as follows:

$\dot{E} x_{d, \text { con }}=\dot{m}_{7}\left(\dot{E} x_{7}-\dot{E} x_{8}\right)-\left(1-\frac{T_{0}}{T_{\text {con }}}\right) \dot{Q}_{c o n}$

\subsection{Absorption chiller evaporator}

The mass balance for the absorption chiller evaporator is written as follows:

$\dot{m}_{9}=\dot{m}_{10}$

The energy balance for the absorption chiller evaporator is calculated as follows:

$\dot{m}_{9} h_{9}+\dot{Q}_{\text {eva }}=\dot{m}_{10} h_{10}$

The exergy balance for the absorption chiller evaporator is obtained as follows:

$\dot{E} x_{d, e v a}=\dot{m}_{10}\left(\dot{E} x_{9}-\dot{E} x_{10}\right)+\left(1-T_{0} / T_{c o n}\right) \dot{Q}_{c o n}$ 


\subsection{Absorption chiller absorber}

The concentration and mass balance equation for absorber is written as follows:

$\dot{m}_{1} x_{1}=\dot{m}_{6} x_{6}+\dot{m}_{10} x_{10}$

$\dot{m}_{1}=\dot{m}_{6}+\dot{m}_{10}$

The energy and exergy balance equations for absorber are expressed as:

$$
\begin{aligned}
& \dot{m}_{6} h_{6}+\dot{m}_{10} h_{10}=\dot{m}_{1} h_{1}+\dot{Q}_{a b s} \\
& \dot{m}_{6} \dot{E} x_{6}+\dot{m}_{10} \dot{E} x_{10} \\
& \quad=\dot{m}_{1} \dot{E} x_{1}+\left(1-T_{0} / T_{a b s}\right) \dot{Q}_{a b s}+\dot{E} x_{\mathrm{d}, \mathrm{abs}}
\end{aligned}
$$

\subsection{Absorption chiller pump}

The mass balance and consumption power of the absorption chiller pump are calculated as follows:

$\dot{m}_{1}=\dot{m}_{2}$

$\dot{W}_{p}=\dot{m}_{1}\left(h_{2}-h_{1}\right)$

The energetic coefficient of performance is calculated as follows:

$C O P_{e n}=\dot{Q}_{e v a} / \dot{Q}_{g e n}$

\subsection{Kalina cycle turbine}

The power of Kalina cycle is written as follows:

$\dot{W}_{t, k c}=\dot{m}_{k c}\left(h_{18}-h_{19}\right)$

The turbine isentropic efficiency can be written as follows:

$\eta_{t}=\left(h_{18}-h_{19}\right) / h_{18}-h_{19, s}$

\subsection{Kalina cycle pump}

The Consumption Power of the Kalina cycle pump is calculated as follows:

$\dot{W}_{p, k c}=\dot{m}_{k c}\left(h_{20}-h_{19}\right)$

\subsection{Kalina cycle condenser}

The heat transfer rate in the condenser is written as follows:

$\dot{E} x_{d, c o n, k c}=\left(1-T_{0} / T_{c o n}\right) \dot{Q}_{c o n, k c}$

The energy and exergy efficiency of the Kalina cycle can be written as follows.

$$
\begin{aligned}
& \eta_{e n, k c}=\dot{W}_{\text {net }, k c} / \dot{Q}_{\text {boiler }} \\
& \eta_{\text {ex,kc }}=\dot{\mathrm{W}}_{\text {net,kc }} / \dot{E x}_{\text {boiler }}
\end{aligned}
$$

The net power of the Kalina cycle is calculated as follows:

$\dot{W}_{n e t k c}=\dot{W}_{t, k c}-\dot{W}_{p, k c}$

\section{SYSTEM ENERGY AND EXERGY EFFICIENCY}

Energy and exergy efficiency of the trigeneration system are calculated as follows:

$$
\begin{aligned}
& \eta_{\text {en }, \text { system }}=\frac{\dot{\mathrm{W}}_{\text {tur }}}{\dot{\mathrm{Q}}_{\text {solarcycle }}}+\frac{\dot{\mathrm{Q}}_{\mathrm{dwh}}}{\dot{\mathrm{Q}}_{\text {solarcycle }}} \\
& +\frac{\dot{Q}_{\text {eva }}-\dot{W}_{p, \text { solar }}-\dot{W}_{p, k c}}{\dot{Q}_{\text {solarcycle }}} \\
& \eta_{\text {ex }, \text { sys }}=\frac{\dot{W}_{\text {tur }}+\dot{Q}_{\text {eva }}\left(1-\frac{T_{0}}{T_{\text {eva }}}\right)}{\dot{Q}_{\text {solar }}\left(1-\frac{T_{0}}{T_{\text {sun }}}\right)} \\
& -\frac{\dot{W}_{p, k c}}{\dot{Q}_{\text {solar }}\left(1-\frac{T_{0}}{T_{\text {sun }}}\right)}+\frac{\dot{Q}_{d w h}\left(1-\frac{T_{0}}{T_{d w h}}\right)}{\dot{Q}_{\text {solar }}\left(1-\frac{T_{0}}{T_{\text {sun }}}\right)} \\
& -\frac{\dot{W}_{p, \text { sc }}}{\dot{Q}_{\text {solar }}\left(1-\frac{T_{0}}{T_{\text {sun }}}\right)}
\end{aligned}
$$

\section{ECONOMIC ANALYSIS}

Economic analysis is a powerful tool for evaluating systems. The parameters used in the evaluation of economic analysis include the product cost, the fuel cost, the cost of the process or energy conversion, the cost of equipment, the cost of maintenance and etcetera. Expenses of investment, operating, and maintenance $(Z)$ can be defined as [23]:

$\mathrm{Z}_{k}=\frac{\mathrm{Z}_{k} C R F \varphi}{N \times 3600}$

In equation (45), $\mathrm{Z}_{\mathrm{k}}$ is the cost of purchasing $\mathrm{k}$ components, $(\varphi)$ maintenance and repairing factor and $(N)$ represent the number of the hours of plant operation per year. Annual capital recovery factor $(C R F)$ is defined as follows [23]:

$\mathrm{CRF}=\frac{i \times(i+1)^{n}}{(i+1)^{n-1}}$

where $i$ is the interest rate.

\section{RESULTS AND DISCUSSION}

Table 2. Energy analysis results

\begin{tabular}{cc}
\hline Variable & Value \\
\hline $\begin{array}{c}\text { The heat transfer rate from the } \\
\text { collector to heat transfer fluid } \\
\text { Therminol-66 (MW) }\end{array}$ & 3.53 \\
\hline $\begin{array}{c}\text { The heat transfer rate to the Kalina } \\
\text { cycle (MW) }\end{array}$ & 2.75 \\
\hline $\begin{array}{c}\text { The heat transfer rate to the generator } \\
(\mathrm{kW})\end{array}$ & 35 \\
\hline Turbine production power $(\mathrm{kW})$ & 546.7 \\
\hline $\begin{array}{c}\text { Evaporator cooling load (kW) } \\
\text { heater (kW) }\end{array}$ & 28.52 \\
\hline $\begin{array}{c}\text { Heat transfer rate domestic water } \\
\text { performance }\end{array}$ & 321.57 \\
\hline $\begin{array}{c}\text { Absorption chiller coefficient of } \\
\text { The system energy efficiency }(\%)\end{array}$ & 0.8145 \\
\hline
\end{tabular}


Using the Equations and input data, the trigeneration system was modeled based on MATLAB software. The results of energy analysis are shown in Table 2. According to Table 2, the energy efficiency of the system, Absorption chiller coefficient of performance, turbine output power and cooling load are $17.37 \%, 0.8145,546.7$ and $28.52 \mathrm{~kW}$, respectively.

The second law of thermodynamics is the verification of thermodynamic systems. In the perspective of exergy or useful energy, the system is evaluated by the destruction exergy. The results of destruction exergy analysis are shown in Table 3 below. The solar cycle has the highest destructed exergy due to the high temperature gradient in this cycle. The total system exergy efficiency is approximately $18.82 \%$ and defined as the macroscopic ratio of input and output energies. Economic analysis of renewable energy is important. Purchase cost rate is shown in Table 4. According to Table 4, the highest purchase cost rate is for the solar collector approximately $57 \%$ of the total cost. The purchase cost rate of the collector is a function of collector size.

The term of thermal conductivity is due to the finite heat transfer in heat exchanger. The results of calculating the thermal conductivity are presented in Table 5.

Table 3. Exergy analysis results in subsystems

\begin{tabular}{cc}
\hline Variable & $\begin{array}{c}\text { Base case design } \\
\text { value }\end{array}$ \\
\hline $\begin{array}{c}\text { Exergy destruction in the solar cycle } \\
(\mathrm{MW})\end{array}$ & 2.402 \\
\hline $\begin{array}{c}\text { Exergy destruction in the Kalina cycle } \\
(\mathrm{kW})\end{array}$ & 264.61 \\
\hline $\begin{array}{c}\text { Exergy destruction in the absorption } \\
\text { chiller }(\mathrm{kW})\end{array}$ & 8.67 \\
\hline System exergy efficiency $(\%)$ & 18.82 \\
\hline
\end{tabular}

Table 4. Purchase cost rate

\begin{tabular}{cc}
\hline Variable & $\begin{array}{c}\text { Purchase cost } \\
\text { base case }\end{array}$ \\
\hline Parabolic solar collector $(\$ / \mathrm{h})$ & 5.453 \\
Domestic water heater $(\$ / \mathrm{h})$ & 0.00002 \\
Kalina cycle condenser $(\$ / \mathrm{h})$ & 0.1128 \\
Absorption chiller $(\$ / \mathrm{h})$ & 0.3332 \\
Kalina cycle Pump $(\$ / \mathrm{h})$ & 0.3032 \\
Boiler $(\$ / \mathrm{h})$ & 2.117 \\
Turbine $(\$ / \mathrm{h})$ & 1.315 \\
Total cost rate $(\$ / \mathrm{h})$ & 9.63 \\
\hline
\end{tabular}

Table 5. Thermal conductivity calculation results

\begin{tabular}{cc}
\hline Component & Thermal conductivity \\
\hline Boiler $(\mathrm{kW} / \mathrm{K})$ & 41.11 \\
\hline Domestic water heaters $(\mathrm{kW} / \mathrm{K})$ & 9.28 \\
\hline The Kalina condenser $(\mathrm{kW} / \mathrm{K})$ & 56.94 \\
\hline Absorption chiller generator $(\mathrm{kW} / \mathrm{K})$ & 0.1 \\
\hline Absorption chiller condenser $(\mathrm{kW} / \mathrm{K})$ & 1.25 \\
\hline Absorption chiller absorber $(\mathrm{kW} / \mathrm{K})$ & 0.11 \\
\hline Absorption chiller evaporator $(\mathrm{kW} / \mathrm{K})$ & 1.17 \\
\hline Total thermal conductivity $(\mathrm{kW} / \mathrm{K})$ & 109.96 \\
\hline
\end{tabular}

Summary of results and findings is shown in Figure 4.

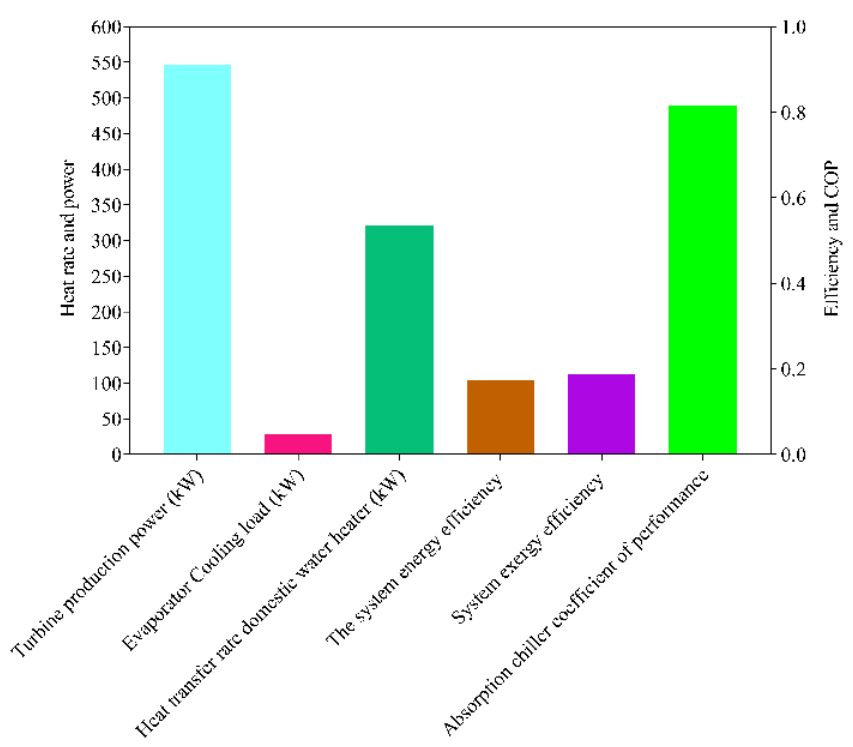

Figure 4. Summary of results and findings

\section{OPTIMIZATION}

Table 6. optimization based on the criterion of maximum power

\begin{tabular}{cc}
\hline Variable & value \\
\hline The Rankine cycle pressure ratio & 141.37 \\
\hline Mass flow rate of solar cycle $(\mathrm{kg} / \mathrm{s})$ & 6 \\
\hline Mass flow rate of Kalina cycle $(\mathrm{kg} / \mathrm{s})$ & 2.0802 \\
\hline Thermal conductivity of boiler $\mathrm{kW} / \mathrm{K})$ & 80.95 \\
\hline $\begin{array}{c}\text { Thermal conductivity of domestic water } \\
\text { heater }(\mathrm{kW} / \mathrm{K})\end{array}$ & 10.128 \\
\hline $\begin{array}{c}\text { Thermal conductivity of adsorption chiller } \\
\text { generator }(\mathrm{kW} / \mathrm{K})\end{array}$ & 0.1025 \\
\hline $\begin{array}{c}\text { Thermal conductivity of adsorption chiller } \\
\text { condenser }(\mathrm{kW} / \mathrm{K})\end{array}$ & 1.25 \\
\hline $\begin{array}{c}\text { Thermal conductivity of adsorption chiller } \\
\text { absorber }(\mathrm{kW} / \mathrm{K})\end{array}$ & 0.109 \\
\hline $\begin{array}{c}\text { Thermal conductivity of adsorption chiller } \\
\text { evaporator }(\mathrm{kW} / \mathrm{K})\end{array}$ & 1.165 \\
\hline $\begin{array}{c}\text { Thermal conductivity of Kalina cycle } \\
\text { condenser }(\mathrm{kW} / \mathrm{K})\end{array}$ & 54.98 \\
\hline Power $(\mathrm{kW})$ & 700.2 \\
\hline Energy efficiency $(\%)$ & 19.51 \\
\hline Exergy efficiency $(\%)$ & 21.45 \\
\hline The total cost rate $(\$ / \mathrm{h})$ & 10.37 \\
\hline
\end{tabular}

Optimization is defined as to find maximum or minimum dependent variables with variation in decision variables. In this paper, optimization was performed by the genetic algorithm. Genetic algorithm with examining the imitation of biological evolution was invented by Holland [24]. Today, the genetic algorithm has become an evolutionary computing tool. Genetic algorithm is one of the evolutionary methods that performs optimization by random search. The genetic algorithm has two principles: selection and generation; these two principles have been derived from nature [25]. In this paper, objective functions are energy efficiency, exergy efficiency and total cost rate. Decision variables include mass flow rate of solar cycle, mass flow rate of Kalina cycle thermal conductivity of boiler, thermal conductivity of domestic water heater, thermal conductivity of adsorption chiller generator, 
thermal conductivity of adsorption chiller condenser, thermal conductivity of absorption chiller absorber, thermal conductivity of absorption chiller evaporator, thermal conductivity of Kalina cycle condenser, and The Rankine cycle pressure ratio. The results of trigeneration system optimization based on maximum power criterion are shown in Table 6. In order to compare the criteria is used the relative variations relative to base mode as shown in Table 6 .

The produced power, energy efficiency, exergy efficiency and total cost rate increase $28 \%, 12.32 \%$, of $13.97 \%$ and $7.68 \%$, respectively and also, this result is obtained with comparison to the base case. Therefore optimization based on the maximum power criterion, in addition to increasing the total cost rate and power. Optimization based on the maximum energy efficiency criterion is tabulated in Table 7.

Table 7. Optimization based on the criterion of energy efficiency

\begin{tabular}{cc}
\hline Variable & value \\
\hline The Rankine cycle pressure ratio $(\mathrm{kW} / \mathrm{K})$ & 127.99 \\
\hline Mass flow rate of solar cycle & 6 \\
\hline Mass flow rate of Kalina Cycle & 2 \\
\hline Thermal conductivity of boiler $(\mathrm{kW} / \mathrm{K})$ & 58.86 \\
\hline $\begin{array}{c}\text { Thermal conductivity of domestic water } \\
\text { heater }(\mathrm{kW} / \mathrm{K})\end{array}$ & 10.13 \\
\hline $\begin{array}{c}\text { Thermal conductivity of adsorption chiller } \\
\text { generator }(\mathrm{kW} / \mathrm{K})\end{array}$ & 0.1025 \\
\hline $\begin{array}{c}\text { Thermal conductivity of adsorption chiller } \\
\text { condenser }(\mathrm{kW} / \mathrm{K})\end{array}$ & 1.2469 \\
\hline $\begin{array}{c}\text { Thermal conductivity of adsorption chiller } \\
\text { absorber }(\mathrm{kW} / \mathrm{K})\end{array}$ & 0.109 \\
\hline $\begin{array}{c}\text { Thermal conductivity of adsorption chiller } \\
\text { evaporator }(\mathrm{kW} / \mathrm{K})\end{array}$ & 1.1652 \\
\hline $\begin{array}{c}\text { Thermal conductivity of Kalina cycle } \\
\text { condenser }(\mathrm{kW} / \mathrm{K})\end{array}$ & 58.92 \\
\hline $\begin{array}{c}\text { Power }(\mathrm{kW}) \\
\text { Energy efficiency }(\%)\end{array}$ & 567.14 \\
\hline Exergy efficiency $(\%)$ & 17.57 \\
\hline \begin{tabular}{c} 
Total cost rate $(\$ / \mathrm{h})$ \\
\hline
\end{tabular}
\end{tabular}

Table 8. Optimization based on the criterion of exergy efficiency

\begin{tabular}{cc}
\hline Variable & value \\
\hline The Rankine cycle pressure ratio $(\mathrm{kW} / \mathrm{K})$ & 143.123 \\
\hline mass flow rate of solar cycle $(\mathrm{kg} / \mathrm{s})$ & 6 \\
\hline mass flow rate of Kalina Cycle $(\mathrm{kg} / \mathrm{s})$ & 2 \\
\hline Thermal conductivity of boiler $(\mathrm{kW} / \mathrm{K})$ & 57.082 \\
\hline $\begin{array}{c}\text { Thermal conductivity of domestic water } \\
\text { heater }(\mathrm{kW} / \mathrm{K})\end{array}$ & 10.127 \\
\hline $\begin{array}{c}\text { Thermal conductivity of adsorption chiller } \\
\text { generator }(\mathrm{kW} / \mathrm{K})\end{array}$ & 0.103 \\
\hline $\begin{array}{c}\text { Thermal conductivity of adsorption chiller } \\
\text { condenser }(\mathrm{kW} / \mathrm{K})\end{array}$ & 1.25 \\
\hline $\begin{array}{c}\text { Thermal conductivity of adsorption chiller } \\
\text { absorber }(\mathrm{kW} / \mathrm{K})\end{array}$ & 0.109 \\
\hline $\begin{array}{c}\text { Thermal conductivity of adsorption chiller } \\
\text { evaporator }(\mathrm{kW} / \mathrm{K})\end{array}$ & 1.1652 \\
\hline $\begin{array}{c}\text { Thermal conductivity of Kalina cycle } \\
\text { condenser }(\mathrm{kW} / \mathrm{K})\end{array}$ & 58.93 \\
\hline $\begin{array}{c}\text { Power }(\mathrm{kW}) \\
\text { Energy efficiency }(\%)\end{array}$ & 567.5 \\
\hline $\begin{array}{c}\text { Exergy efficiency }(\%) \\
\text { Total cost rate }(\$ / \mathrm{h})\end{array}$ & 15.81 \\
\hline
\end{tabular}

Thus, by designing the system according to Table 7; in other words, the maximum energy efficiency criterion, the output power, the energy efficiency and total cost rate increase $3.74 \%$, $6.64 \%$ and $6.023 \%$, respectively; however, but the exergy efficiency decrease $6.64 \%$ approximately relative to the base case. Optimization based on the energy efficiency criterion is an optimization of classical thermodynamics. Optimization based on the maximum energy efficiency criterion leads to an increase in the total cost and power.

Exergy efficiency is widely used as the objective function in thermodynamic analysis. Exergy efficiency is defined as the comparison of several macroscopic forms of energy with different qualities. Optimization results of the trigeneration system based on the maximum exergy efficiency criterion are shown in Table 8. Then, optimization based on the exergy efficiency criterion leads to an increase in exergy efficiency and total cost rate $16.31 \%$ and $5.09 \%$, respectively and a decrease the power output, energy efficiency $34.88 \%$ and $8.98 \%$, respectively.

Comparison of different optimization criteria are presented in figure 5.

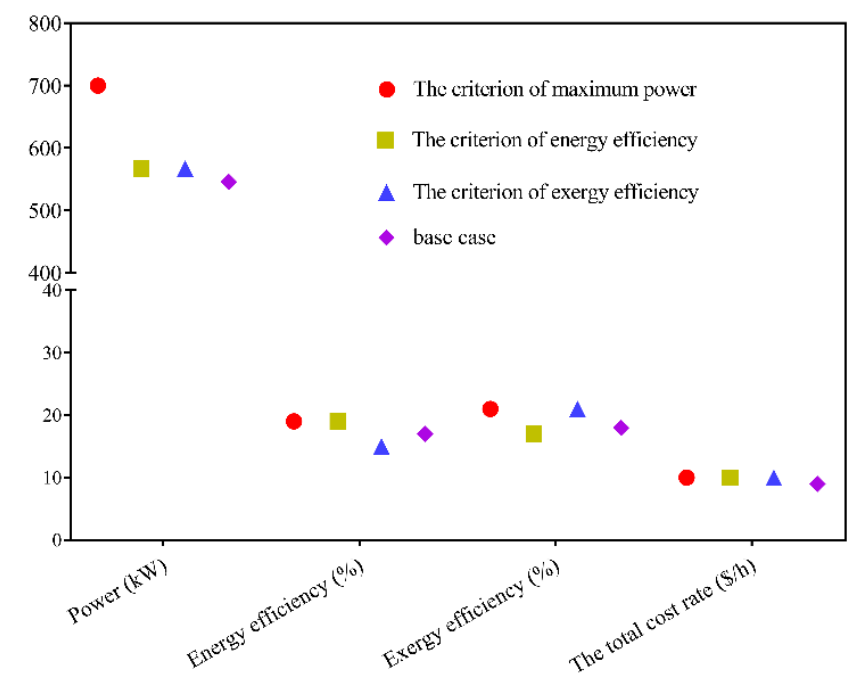

Figure 5. Comparison of different optimization criteria

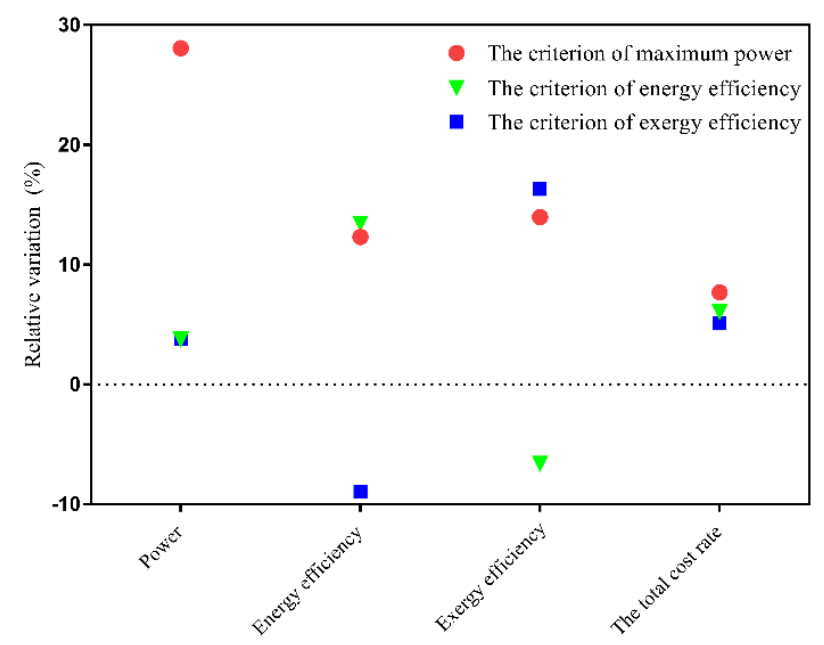

Figure 6. Relative variation of different criteria

As shown in figure 6, the results show that power criteria are superior to energy and exergy efficiency criteria. The present study was designed to determine the effect of power 
evaluation and optimization on the performance of thermodynamic systems. The current study found that power analysis was dominant on efficiency.

\section{CONCLUSION}

One of the ways to achieve sustainable development for developing countries such as Iran is to pay more attention to the potential of renewable energy sources in each climate. Among renewable energies, solar energy is a good alternative to fossil fuels. The climatic and weather conditions in the city of Zahedan provide good conditions for the operation of solar systems. In this study, energy, exergy and cost analysis and assessment were performed. In this paper, optimization criteria including maximum power, energy, and exergy efficiency were compared with each other. As a result, the criteria based on power are better than criteria based on efficiency, such as energy and exergy efficiency. As a result, the criteria based on power are better than criteria based on efficiency, such as energy and exergy efficiency. Therefore, comparing the power-based and efficiency-based analysis shows that powerbased was closer to the ideal state. Finally, the power analysis was presented as a powerful thermodynamic tool.

\section{REFERENCES}

[1] Dincer I. (2000). Renewable energy and sustainable development: A crucial review. Renewable and Sustainable Energy Reviews 4(2): 157-175. https://doi.org/ 10.1016/S1364-0321(99)00011-8

[2] Teske S, Pregger T, Simon S, Naegler T, Graus W, Lins C. (2011). Energy [R] evolution 2010-a sustainable world energy outlook. Energy Efficiency 4(3): 409-433. https://doi.org/ 10.1007/s12053-010-9098-y

[3] Goswami DY. (1986). Alternative energy in agriculture. CRC Press, Boca Raton 36-57.

[4] Dincer I, Dost S, Li X. (1997). Performance analyses of sensible heat storage systems for thermal applications. International Journal of Energy Research 21(12): 11571171. https://doi.org/10.1002/(SICI)1099114X(19971010)21: $12<1157::$ AID-ER317>3.0.CO;2-N

[5] Ahmadi P, Dincer I. (2010). Exergoenvironmental analysis and optimization of a cogeneration plant system using Multimodal Genetic Algorithm (MGA). Energy. 35(12): https://doi.org/10.1016/j.energy.2010.07.050

[6] Ahmadi P, Dincer I, Rosen MA. (2012). Exergoenvironmental analysis of an integrated organic Rankine cycle for trigeneration. Energy Conversion and Management 64(Supplement C): 447-453. https://doi.org/10.1016/j.enconman.2012.06.001

[7] Khaliq A. (2009). Exergy analysis of gas turbine trigeneration system for combined production of power heat and refrigeration. 13 International Journal of Refrigeration 32(3): 534-545. https://doi.org/10.1016/j.ijrefrig.2008.06.007

[8] Ahmadi P, Rosen MA, Dincer I. (2011). Greenhouse gas emission and exergo-environmental analyses of a trigeneration energy system. International Journal of Greenhouse Gas Control 5(6): 1540-1549. https://doi.org/10.1016/j.ijggc.2011.08.011
[9] Marston CH. (1990). Parametric analysis of the Kalina cycle. Journal of Engineering for Gas Turbines and Power 112(1): 107-116. https://doi.org/10.1115/1.2906464

[10] Wall G, Chuang CC, Ishida M. (1989). Exergy study of the Kalina cycle. Analysis and design of energy systems: analysis of industrial processes. 10(3): 73-77.

[11] Wang J, Yan Z, Zhou E, Dai Y. (2013). Parametric analysis and optimization of a Kalina cycle driven by solar energy. Applied Thermal Engineering 50(1): 408415.

https://doi.org/10.1016/j.applthermaleng.2012.09.002

[12] Chua H, Toh H, Ng K. (2002). Thermodynamic modeling of an ammonia-water absorption chiller. International Journal of Refrigeration 25(7): 896-906. https://doi.org/10.1016/S0140-7007(01)00101-3

[13] Farshi LG, Mahmoudi SS, Rosen M, Yari M, Amidpour M. (2013). Exergoeconomic analysis of double effect absorption refrigeration systems. Energy Conversion and Management 65(Supplement C): 13-25. https://doi.org/10.1016/j.enconman.2012.07.019

[14] Bejan A. (2016). Advanced engineering thermodynamics. John Wiley \& Sons, New York 69-72.

[15] Duffie JA, Beckman WA, Worek WM. (2009). Solar engineering of thermal processes. Academic Press, Boston. 121-217.

[16] Abuelnuor AAA, Saqr KM, Mohieldein SAA, Dafallah KA, Abdullah MM, Nogoud YAM. (2017). Exergy analysis of Garri "2" $180 \mathrm{MW}$ combined cycle power plant. Renewable and Sustainable Energy Reviews 79(Supplement C): 960-969. https://doi.org/10.1016/j.rser.20 17.05.077

[17] Kalogirou SA. (2002). Parabolic trough collectors for industrial process heat in Cyprus. Energy 27(9): 813-830. https://doi.org/10.1016/S0360-5442(02)00018-X

[18] Kalogirou SA. (2009). Solar Energy Engineering: Processes and Systemsed. 9780123745019.

[19] Kalogirou SA, Lloyd S, Ward J, Eleftheriou P. (1994). Design and performance characteristics of a parabolictrough solar-collector system. Applied Energy 47(4): 341-354. https://doi.org/10.1016/0306-2619(94)90041-8

[20] Ozlu S, Dincer I. (2015). Development and analysis of a solar and wind energy based multigeneration system. Solar Energy 122(Supplement C): 1279-1295. https://doi.org/10.1016/j.solener.2015.10.035

[21] Ozlu S, Dincer I. (2016). Analysis and evaluation of a new solar energy - based multigeneration system. International Journal of Energy Research. 40(10): 13391354. https://doi.org/10.1002/er.3516

[22] Ozlu S, Dincer I. (2016). Performance assessment of a new solar energy-based multigeneration system. Energy 112(Supplement $\quad$ C): 164-178. https://doi.org/10.1016/j.energ y.2016.06.040

[23] Goosen MFA, Sablani SS, Shayya WH, Paton C, AlHinai H. (2000). Thermodynamic and economic considerations in solar desalination. Desalination 129(1): 63-89. https://doi.org/10.1016/S0011-9164(00)00052-7

[24] Holland JH. (1992). Genetic algorithms. Scientific American 267(1): 66-73.

[25] Davis L. (1991). Handbook of genetic algorithms. Van Nostrand Reinhold, New York 2-12. 


\section{NOMENCLATURE}

$A_{a} \quad$ Aperture area, $m^{2}$

$A_{r} \quad$ Received area,$m^{2}$

$F^{\prime} \quad$ Collector efficiency factor

$F_{R} \quad$ Heat removal factor

$\dot{Q} \quad$ Heat transfer rate, $k W$

$T_{a}$

$T_{f}$

$T_{s}$

$\dot{m}$

A

$h$

D

G

K

$L$

$U$

Z

Diameter, $m$
Ambient temperature, $K$

Inlet collector temperature, $K$

Thermal Storage Temperature, $K$

Mass flow rate, $\mathrm{Kg} / \mathrm{s}$

Area, $m^{2}$

Specific enthalpy, $\mathrm{kJ} / \mathrm{kg}$, Heat transfer coefficient, $\mathrm{kW} / \mathrm{m}^{2} \mathrm{~K}$

Solar radiation rate, $W / \mathrm{m}^{2}$

Thermal conductivity coefficient, $\mathrm{KW} / \mathrm{m}^{2} \mathrm{~K}$

Length, $m$

Heat transfer coefficient, $\mathrm{kW} / \mathrm{m}^{2} \mathrm{~K}$

Purchase cost, $\$$

\section{Subscripts}

$\begin{array}{ll}\text { abs } & \text { Absorption } \\ \text { ap } & \text { Aperture } \\ \text { con } & \text { Condenser } \\ \text { dwh } & \text { Domestic water heater } \\ \mathrm{i} & \text { Inlet } \\ \mathrm{kc} & \text { Kalina cycle } \\ \text { state } & 1 \ldots 50 \\ \text { numbers } & \end{array}$

\section{Greek letters}

$\begin{array}{ll}\alpha & \text { Absorptivity } \\ \eta & \text { Efficiency } \\ \xi & \text { Insulation thickness, } m \\ \rho & \text { Specular reflectance of the concentrator } \\ \tau & \text { Effect of angle of incidence }\end{array}$

